\title{
ULTRAPOTASSIC MAGMAS ALONG THE FLANKS OF THE OLIGO-MIOCENE RIO GRANDE RIFT, U.S.A.: MONITORS OF THE ZONE OF LITHOSPHERIC MANTLE EXTENSION AND THINNING BENEATH A CONTINENTAL RIFT
}

\author{
Gibson, ${ }^{(1)}$ S.A.; Thompson, ${ }^{(1)}$ R.N.; Leat, ${ }^{(2)}$ P.T.; Morrison, ${ }^{(3)}$ M.A.; Hendry, ${ }^{(3)}$ G.L. \& Dickin, ${ }^{(4)}$ A.P.
}

(1)Department of Geological Sciences, University of Durham, South Road, Durham, DH1 3LE (UK); (2)British Antarctic Survey, High Cross, Madingly Road, Cambridge, CB3 OET (UK); (3)School of Earth Sciences, University of Birmingham, Edgbaston, Birmingham, B15 2TT (UK); (4)Department of Geology, McMaster University, 1280 Main

Street West, Hamilton, L85 4M1 (Canada)

Recent theoretical studies of rift tectonics have concluded that their observed geophysical features require that: (1) extension affects a much wider zone of the underlying lithospheric mantle than the crust; (2) early extension involves a comparatively wide zone, that narrows with time (e.g. Rowley \& Sahagian, 1986; Buck et al., 1988). The Neogene evolution of the segment of the Rio Grande rift between the Great Plains and Colorado Plateau shows this theoretical pattern clearly. The width of the crustal extension zone narrowed from $\sim 170 \mathrm{~km}$ in the Oligo-Miocene to $\sim 50 \mathrm{~km}$ in the Pliocene (e.g. Aldrich et al., 1986; Fig.1). In contrast, both gravity and teleseismic studies (Parker et al., 1984) indicate that the current width of the zone of thinned lithospheric mantle $(\beta=2-3)$ beneath the rift is $\sim 750 \mathrm{~km}$ wide. This is presumably the aggregate result of all Neogene extension in the area, most of which took place in the Oligo-Miocene. We have sampled a diverse range of Oligo-Miocene magmatism (ranging from ultrapotassics to $\mathrm{Hy}$ - and Ne-normative basalts) extending $\sim 650 \mathrm{~km}$ across the thinned lithospheric mantle zone at $36-38^{\circ} \mathrm{N}$, from the Navajo Igneous Province, Arizona, to Two Buttes, SE Colorado. The section is centered on the present day rift (Espanola Basin) and crosses L. Miocene hypabyssal intrusion complexes on the rift shoulders at Dulce and Riley, west of the rift, and Spanish Peaks to the east. A geochemical traverse along this section shows a spatially symmetrical variation in element and oxide ratios, such as $\mathrm{Na}_{2} \mathrm{O} / \mathrm{K}_{2} \mathrm{O}$ (Fig. 2) and $\mathrm{Ba} / \mathrm{Nb}$, around the physiographic Rio Grande rift. Average $\mathrm{Na}_{2} \mathrm{O} / \mathrm{K}_{2}^{2} \mathrm{O}$ ratios are as low as 0.4 in L. Miocene vents and intrusions above thick lithosphere $(\sim 150 \mathrm{~km})$ on the stable platforms flanking the rift. Examples of rock types from this tectonic setting are the "kimberlites" and minettes of the Navajo Province and minettes at Two Buttes. Average $\mathrm{Na}_{2} \mathrm{O} / \mathrm{K}_{2} \mathrm{O}$ ratios increase towards the rift shoulders (1.2) and range from 1.4 to 8.66 in the centre of the rift where the lithosphere is $\sim 75 \mathrm{~km}$ thick. The large range in $\mathrm{Na}_{2} \mathrm{O} / \mathrm{K}_{2} \mathrm{O}$ ratios in the Espanola Basin reflects the occurrence of both alkali and tholeiitic $L$. Miocene basalts in that area. A similar symmetrical spatial variation is apparent in $\mathrm{Sr}$ and $\mathrm{Nd}$ isotope ratios; average ${ }^{87} \mathrm{Sr} /{ }^{86} \mathrm{Sr}$ ratios range from 0.70713 on the flanks to 0.70433 in the centre of the rift.

The variation in average $\mathrm{Na}_{2} \mathrm{O} / \mathrm{K}_{2} \mathrm{O}$ ratios broadly parallels the corresponding teleseismic lithosphere thickness protile and is a mirror image of the gravity profile. Tectonic reconstructions show that the Farallon Plate was being subducted eastwards under the area at $24 \mathrm{Ma}$ and the seismic tomographic study of Grand (1987) has provided direct evidence for this hypothesis. It has been suggested that the upward migration of volatiles from the sinking slab were responsible for mantle metasomatism and consequent ultrapotassic magmatism in the Navajo Province from 28-23 Ma (Laughlin et al., 1986; Rowell \& Edgar, 1983). However the symmetrical ratio plots of incompatible elements, $\mathrm{Na}_{2} \mathrm{O} / \mathrm{K}_{2} \mathrm{O}$ and isotopes of magmas in a $650 \mathrm{~km}$ zone centered on the rift axis suggests that the ultrapotassic magmas on the stable flanks and shoulders of the rift are not directly

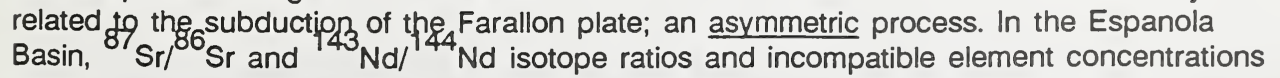
are comparable to those of ocean island basalts (OIB's), e.g. Hawaii. This suggests that 
the magmas in the rift axis, both tholeitic and alkalic, were derived from an asthenospheric source. On the stable rift flanks almost all of the magmas are highly enriched in strongly incompatible elements and are depleted in high-field-strength elements such as $\mathrm{Nb}$ and $\mathrm{Ta}$. These compositions are more typical of lithosphere-derived magmas (e.g. Thompson et al., 1990); a view concordant with the evidence of their radiogenic isotope ratios. The majority of dykes on the rift shoulders show similar elemental enrichments and depletions to the intrusions on the rift flanks but rare OIB-type magmas are also present. Our interpretations of magmatism across the rift zone are in agreement with those of Roden et al., (1990) who have recently suggested that the minettes of the Navajo Province are the a result of mixing melts from asthenospheric and lithospheric mantle sources. They suggest that the radiogenic Nd-isotope ratios of the peridotite xenoliths in the Navajo magmas reflects their long term isolation from mantle convection and that these inclusions are not samples of recently subducted lithosphere. The base of the lithosphere may be metasomatised by the percolation of small melt fractions from asthenosphere (McKenzie, 1989). Remelting of this underlying metasomatised lithosphere by stretching and decompression in the first phase of extension of the Rio Grande rift may explain the symmetrical occurrence of ultrapotassic magmatism in our sampled section. Such a model does not satisfactorily explain the lack of strongly potassic compositions amongst the Oligo-Miocene magmatism of the rift axis. However, this axis has a marked tendency to link sites of substantial Oligocene pre-rift magmatism along the Southern Rocky Mountains. These earlier liquids may have heated the sub-continental lithospheric mantle sufficiently to melt out any pre-existing fusible potassic fractions before rifting began.

\section{References.}

Aldrich, M.J., Jr., Chapin, C.E. \& Laughlin, A.W., 1986. Stress history and tectonic development of the Rio Grande rift, New Mexico. Journal of Geophysical Research, 91, 6199-6211.

Buck, R.W., Martinez, F., Steckler, M.S. \& Cochran, J.R., 1988. Tectonics, 7, 213-234. Cordell, L., 1982. Extension in the Rio Grande rift. Journal of Geophysical Research, 87, 8561-8569.

Grand, S.P., 1987. Tomographic inversion for shear velocity beneath the North american Plate. Journal of Geophysical Research, 92, 14065-14090.

Laughlin, A.W., Aldrich, M.J., Shafiqullah, M. \& Husler, J., 1986. Tectonic implications of the age, composition and orientation of lamprophyre dikes, Navajo volcanic field, Arizona. Earth and Planetary Science Letters, 76, 361-374.

McKenzie, D. P., 1989. Some remarks on the movement of small melt fractions in the mantle. Earth and Planetary Science Letters, 95, 53-72.

Parker, E.C., Davis, P.M., Evans, J.R., Iyer, H.M. \& Olsen, K.H., 1984. Upwarps of anomalous asthenosphere beneath the Rio Grande rift. Nature, 312, 354-356.

Roden, M.F., Smith, D. \& Murthy, V.R. 1990. Chemical constraints on lithosphere composition and evolution beneath the Colorado Plateau. Journal of Geophysical Research, 95, 2811-2831.

Rowell, W.F. \& Edgar, A.D., 1983. Cenozoic potassium-rich mafic volcanism in the western USA: its relationship to deep subduction. Journal of Geology, 91, 338-341.

Rowley, D.B. \& Sahagian, D., 1988. Depth dependent stretching: A different approach. Geology, 14, 32-35.

Thompson, R.N., Leat, P.T., Dickin, A.P., Morrison, M.A., Hendry, G.L. \& Gibson, S.A., 1990. Strongly potassic mafic magmas from lithosperic mantle sources during continental extension and heating: evidence from Miocene minettes of northwest Colorado, USA. Earth and Planetary Science Letters, 98, 139-153. 


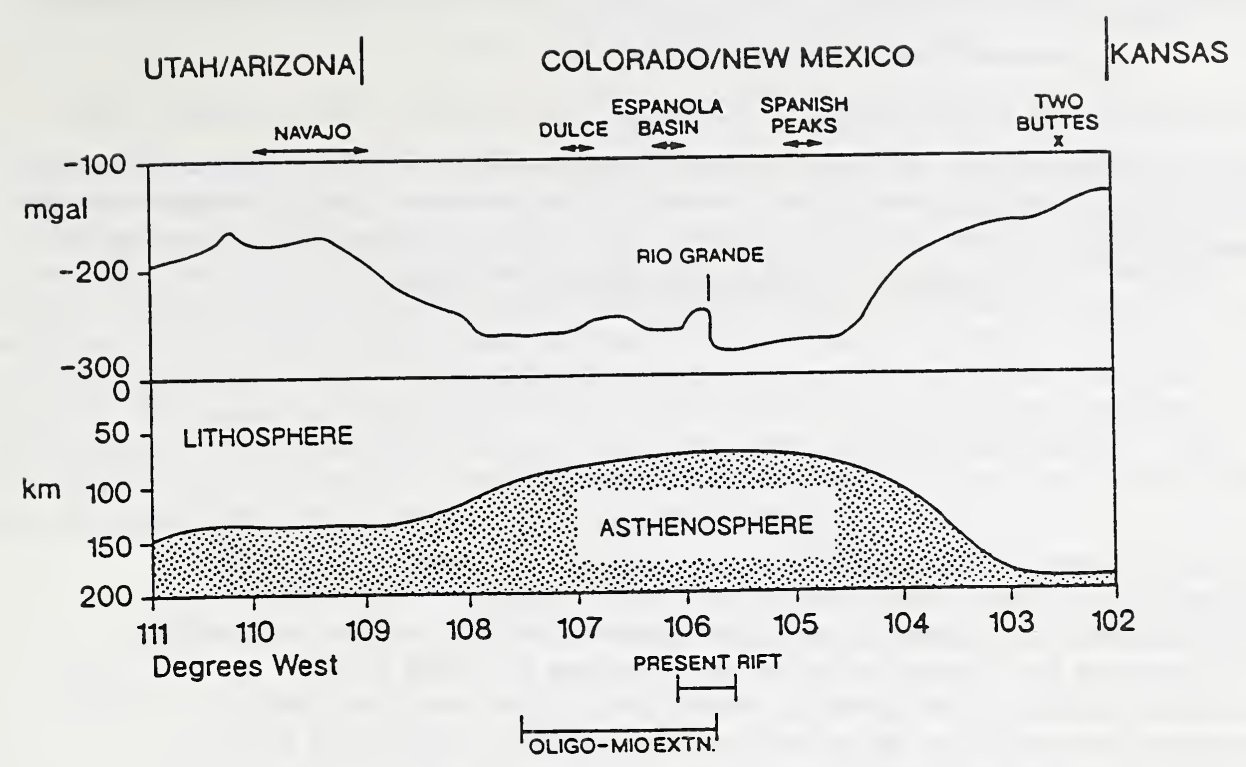

Fig. 1. Crustal structure at approximately $37^{\circ} \mathrm{N}$ beneath the Colorado Plateau, Rio Grande rift and Great Plains, from the gravity study of Cordell (1982) and the teleseismic study of Parker et al. (1984).

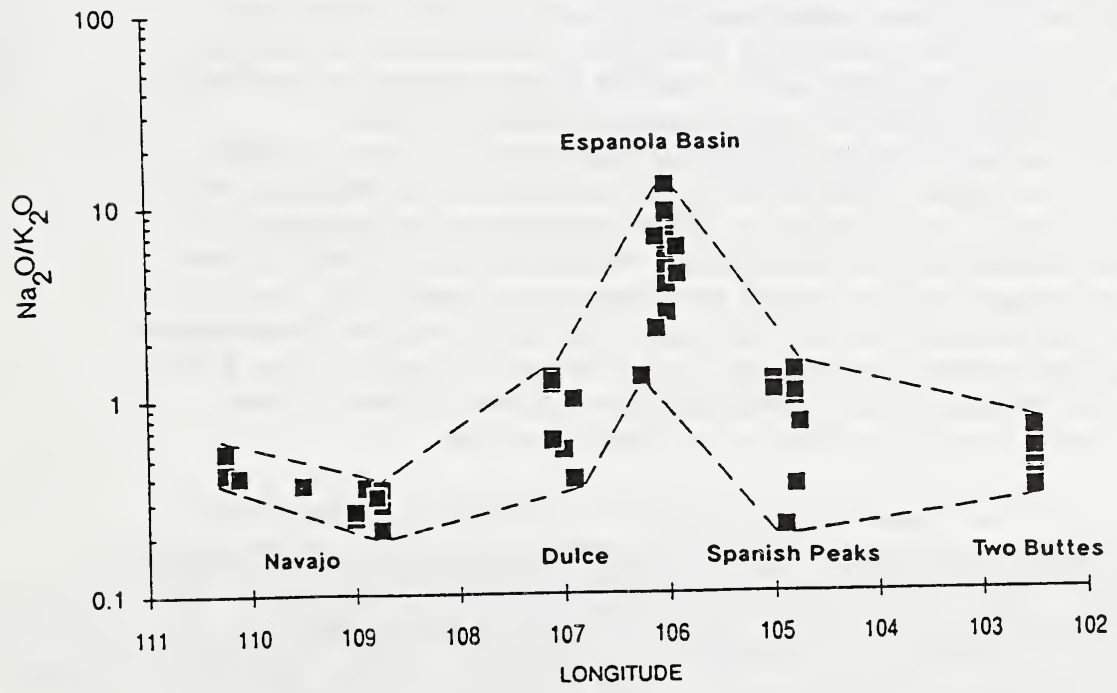

Fig. 2. Variation in alkali content of Oligo-Miocene magmas across the Rio Grande rift between $36^{\circ}$ and $38^{\circ} \mathrm{N}$. 